\title{
ÁLTALÁNOSÍTOTT RELATÍV KONSZENZUS - ÉLES KONVERGENCIATÉTELEK
}

\author{
GERENCSÉR BALÁZS ÉS GERENCSÉR LÁSZLÓ
}

\begin{abstract}
A dolgozat egy hálózatokon definiált relatív konszenzus (ratio consensus) probléma megoldására a [7] és [2] dolgozatokban kifejlesztett push-sum vagy súlyozott pletyka (weighted gossip) algoritmus lényeges általánosítására vonatkozó friss, éles konvergenciatételek rövid összefoglalása [4] alapján. Az általánosítás egy lényeges eleme, hogy a hálózati dinamikát nem-negatív mátrixok egy szigorúan stacionárius, ergodikus, szekvenciálisan primitív sorozata írja le. Következményként megadjuk a push-sum algoritmus pontos konvergencia sebességét, csomagvesztést is megengedve, ld. [5].
\end{abstract}

\section{Bevezetés}

A dolgozat célja egy hálózatokon megfogalmazott számítási probléma, az ún. ratio consensus (adekvát magyar fordításban relatív konszenzus) probléma kapcsán kifejlesztett elosztott, aszinkron algoritmus (push-sum vagy weighted gossip), ld. [7], [2], és annak lényegi általánosítása konvergenciájával kapcsolatos éles eredmények rövid bemutatása, döntöen a [4] dolgozat kiemelt eredményei alapján. A probléma röviden szemléltethető úgy, hogy egy irányított hálózat csúcsaiban elhelyezett $w^{i}>0$ mennyiségü és $x^{i} / w^{i}$ koncentrációjú oldatot akarunk a hálózat által megengedett lokális interakciókkal összekeverni úgy, hogy határértékben minden csúcsban azonos, $\sum_{i} x^{i} / \sum_{i} w^{i}$ koncentrációjú oldat legyen.

A relatív konszenzus problémájának technikai kerete egy kommunikációs gráf, amelyet egy $G=(V, E)$ irányított gráf jelenít meg, amelynek minden csúcsában adott egy $x^{i}$ és $w^{i} \geq 0$ valós értékü számpár, amelyeket értékeknek és súlyoknak nevezünk, úgy, hogy nem lehet a súlyok mindegyike 0. A probléma ekkor a $\sum_{i} x^{i} / \sum_{i} w^{i}$ hányados kiszámítása, minden csúcsban, csak a $G=(V, E)$ által megengedett lokális interakciókat végezve, éspedig aszinkron módon.

A push-sum algoritmus eredeti, legegyszerübb alakja: legyen a csúcsok száma $|V|=p$, és jelölje $x=\left(x^{1}, \ldots, x^{p}\right)^{\top}$ kezdeti értékek vektorát a 0 időpillanatban, a kezdeti súlyok vektora pedig legyen $w=\left(w^{1}, \ldots, w^{p}\right)^{\top}=(1, \ldots, 1)^{\top}=$ : 1. Az $n$ időpontban válasszunk ki véletlenszerüen, függetlenül, egyenletes eloszlás szerint egy $f_{n}=(i, j) \in E$ irányított élt. Ennek végpontjaiban egyidejűleg újítjuk fel az 
értékeket és a súlyokat a következő módon: a küldő fél, $i$ kezdeményez egy tranzakciót, amelynek során a saját értékeinek és súlyainak azonos $\alpha_{j i}:=1 / 2$, hányadát elküldi a fogadó félnek, $j$-nek, aki ezeket saját értékéhez, ill. súlyához hozzáadja, vagy másképp szólva, a megosztott oldatot saját oldatához keveri. Az algoritmus általánosabb alakjában a kezdeti súlyokra csak a $w \geq 0, w \neq 0$ feltevéssel élünk, az élek kiválasztása függetlenül, de él-specifikus valószínüséggel történik, továbbá egy tranzakció során a megosztási hányad tetszőleges $0<\alpha_{j i}<1$ lehet.

A push-sum algoritmus két szép alkalmazása egy nagy (irányítatlan) hálózat szomszédsági mátrixának elosztott spektrál-analízise [8], ill. egy hálózatokon definiált szeparábilis konvex optimalizálási probléma elosztott megoldása [14]. A push-sum fenti algoritmus véletlen csomagvesztéseket is megengedő általánosítását elsőként az [5] dolgozat vizsgálta.

A push-sum algoritmus által definiált hálózati dinamika az alábbi módon írható le. Jelöljék $x_{n-1}$ és $w_{n-1}$ az $n-1$ időpontbeli érték-, ill. súlyvektorokat. Ekkor

$$
x_{n}=A_{n} x_{n-1}, \quad w_{n}=A_{n} w_{n-1} \quad n \geq 1,
$$

ahol $A_{n}$ egy $p \times p$-es független, azonos eloszlás szerint választott véletlen, oszlopsztochasztikus mátrix. Csomagvesztés esetén az oszlopösszeg legfeljebb 1. A pushsum algoritmus egy természetes kiterjesztését kapjuk, ha $A_{n}$ értékkészlete $p \times p$-es nem-negatív, véletlen mátrixok egy tetszőleges $\mathcal{A}$ halmaza lehet. Egy további kiterjesztést kapunk, ha az interakcióban részt vevő, egymást követő párokat egy észszerünek tűnő, jó keveredést ígérő terv szerint választjuk. Így a következő általános problémát fogalmazhatjuk meg. Tekintsük $p \times p$-es nem-negatív, véletlen mátrixok egy szigorúan stacionárius, ergodikus $\left(A_{n}\right), n \geq 1$ sorozatát. Legyenek az $x, w \in \mathbb{R}^{p}$ a kezdeti értékek, ill. súlyok vektorai úgy, hogy $w \geq 0, w \neq 0$. Jelölje $e_{i}$ azt az egységvektort, amelynek $i$-dik koordinátája 1 . Célunk az

$$
e_{i}^{\top} A_{n} A_{n-1} \cdots A_{1} x / e_{i}^{\top} A_{n} A_{n-1} \cdots A_{1} w, \quad i=1, \ldots, p
$$

hányadosok (koncentrációk) aszimptotikus viselkedésének a tanulmányozása.

A dolgozat felépítése: elsőként röviden bemutatjuk a felhasznált matematikai segédeszközöket, nevezetesen a véletlen mátrixok szorzatára vonatkozó alapvető eredményeket, a Fürstenberg-Kesten tételt, [3], ill. az Oseledec tétel egyszerüsített alakját, [9], [12]. A következőkben bevezetjük a szekvenciálisan primitív nemnegatív mátrix folyamatok fogalmát, majd bemutatunk egy normalizált szorzatokra vonatkozó eredményt, az [1] dolgozat eredményének egy kiterjesztését. A dolgozat fő eredményeit a 5.1-5.3. Tételekben fogalmazzuk meg, amelyek éles felső korlátot adnak az általánosított push-sum algoritmus m.m. (majdnem mindenütt) értett exponenciális konvergenciájának a sebességére. Ezeknek a push-sum algoritmusra történő alkalmazását fogalmazza meg a 6.1. Tétel. A dolgozat kiegészíti és továbbfejleszti a [10] és [13] dolgozatokban közölt módszereket és eredményeket. 


\section{Technikai segédeszközök}

2.1. Állítás. (Fürstenberg és Kesten tétele) Legyen $\left(A_{n}\right), n \geq 1$ véletlen, $p \times p$-es mátrixok egy szigorúan stacionárius, ergodikus folyamata egy $(\Omega, \mathcal{F}, \mathcal{P})$ valószínüségi tér felett, amelyre teljesül a $\mathbb{E} \log ^{+}\left\|A_{1}\right\|<\infty$ feltétel. Ekkor a

$$
\lambda_{1}=\lim _{n} \frac{1}{n} \log \left\|A_{n} A_{n-1} \cdots A_{1}\right\|<\infty \quad \text { m.m. }
$$

limesz létezik, és egyenlő az alábbiakkal:

$$
\lim _{n} \frac{1}{n} \mathbb{E} \log \left\|A_{n} A_{n-1} \cdots A_{1}\right\|=\inf _{n} \frac{1}{n} \mathbb{E} \log \left\|A_{n} A_{n-1} \cdots A_{1}\right\| .
$$

Megjegyezzük, hogy $\lambda_{1}=-\infty$ érték is megengedett. Az $A_{n} A_{n-1} \cdots A_{1}$ szorzat egy finomabb karakterizációját adja Oseledec tétele, [9]. Ennek megfogalmazásához egy rövid kitérőt kell tennünk a Ljapunov exponensek világába, ld. [6]. Legyen $\left(A_{n}\right), n \geq 1 p \times p$-es mátrixok egy fix sorozata. Tetszőleges $x \in \mathbb{R}^{p}$-re definiáljuk az $x$ vektornak az $\left(A_{n}\right)$ sorozatra vonatkozó $\lambda(x)$ Ljapunov exponensét az alábbiak szerint:

$$
\lambda(x):=\limsup _{n} \frac{1}{n} \log \left|A_{n} A_{n-1} \cdots A_{1} x\right| .
$$

Tekintsük ezután tetszőleges kiterjesztett értelemben vett $-\infty \leq \mu \leq+\infty$ valós számra az alábbi halmazt:

$$
L_{\mu}=\left\{x \in \mathbb{R}^{p}: \lambda(x) \leq \mu\right\} .
$$

Könnyü látni, hogy $L_{\mu}$ az $\mathbb{R}^{p}$ vektortér lineáris altere, amelyre nyilvánvaló módon $L_{\mu} \subset L_{\mu^{\prime}}$ ha $\mu \leq \mu^{\prime}$, továbbá $L_{\mu}$ jobbról folytonos függvénye $\mu$-nek. Legyen $\mu_{1}$ a legkisebb $\mu$, amelyre $\mathbb{R}^{p}=L_{\mu}$. A fentiek alapján létezik véges sok valós szám $+\infty \geq \mu_{1}>\ldots>\mu_{q} \geq-\infty$, amelyekre $\mathbb{R}^{p}=L_{\mu_{1}} \supsetneq L_{\mu_{2}} \ldots \supsetneq L_{\mu_{q}} \supsetneq\{0\}$, úgy, hogy $\mu_{r}>\mu \geq \mu_{r+1}, r=1, \ldots, q-1$, ill. $\mu_{q}>\mu, r=q$ esetén

$$
L_{\mu}=L_{\mu_{r+1}}, \quad \text { ill. } \quad L_{\mu}=\{0\} .
$$

Innen következik, hogy $1 \leq r \leq q-1$-re

$$
x \in L_{\mu_{r}} \backslash L_{\mu_{r+1}} \text {-re } \lambda(x)=\mu_{r},
$$

és persze $x \in L_{\mu_{q}}$ esetén $\lambda(x)=\mu_{q}$. Legyen az $L_{\mu_{r}}$ dimenziója $i_{r}, 1 \leq r \leq q$, így tehát $p=i_{1}>i_{2}>\ldots>i_{q}>0$, és legyen $i_{q+1}=0$. Definiáljuk a Ljapunov exponensek teljes $\lambda_{1} \geq \lambda_{2} \geq \ldots \geq \lambda_{p}$ spektrumát az alábbi módon:

$$
\lambda_{i}=\mu_{r} \quad \text { ahol } \quad i_{r} \geq i>i_{r+1} .
$$

Ha már most $\left(A_{n}\right)=\left(A_{n}(\omega)\right)$ egy szigorúan stacionárius, ergodikus folyamat realizációja, akkor a fenti észrevétel nem-triviális kiterjesztésével a következő megragadóan szép eredményt kapjuk, amelyet (kissé bővebb alakban) elöször Oseledec 
bizonyított a [9] dolgozatban, majd - gyengébb feltételek mellett - az eredményeket tovább pontosította a [12] dolgozat.

2.2. Állítás. (Oseledec tétel) Legyen $\left(A_{n}\right), n \geq 1$ a 2.1. Állítás szerinti $p \times p$-es mátrix-értékü sztochasztikus folyamat. Ekkor létezik az eseménytér egy 1 valószínüségü $\Omega^{\prime} \in \mathcal{F}$ halmaza úgy, hogy minden $\omega \in \Omega^{\prime}$-re, és egyidejüleg minden $x \in \mathbb{R}^{p}$-re az alábbi limesz létezik:

$$
\lambda(x)=\lim _{n} \frac{1}{n} \log \left|A_{n} A_{n-1} \cdots A_{1} x\right| \quad \text { m.m. }
$$

Továbbá, a $\lambda_{1} \geq \lambda_{2} \geq \ldots \geq \lambda_{p}$, Lyapunov exponensek, amelyek a $-\infty$ értéket is felvehetik, és azok multiplicitásai, nem függenek $\omega \in \Omega^{\prime}$-töl.

A [12] dolgozatban közölt elemzésböl következik, hogy az $M_{n}$ szorzat

$$
M_{n}=U_{n} \Sigma_{n} V_{n},
$$

szinguláris érték felbontására (SVD), ahol $U_{n}, V_{n}$ ortonormális mátrixok és $\Sigma_{n}$ diagonális a $\sigma_{n}^{1} \geq \sigma_{n}^{2} \ldots \geq \sigma_{n}^{p} \geq 0$ diagonális elemekkel, teljesül az alábbi:

$$
\lambda_{k}=\lim _{n} \frac{1}{n} \log \sigma_{n}^{k} \quad \text { m.m. } \quad k=1, \ldots, p .
$$

Az Oseledec tétel állítja az alábbi határérték létezését is:

$$
\lim _{n}\left(M_{n}^{T} M_{n}\right)^{1 / 2 n}=\lim _{n} V_{n}^{T} \Sigma_{n} V_{n} \quad \text { m.m. }
$$

A jelen cikkben arra a [12] dolgozat 5. Lemmájának bizonyításában implicite szereplő kapcsolódó eredményre lesz szükségünk, hogy $\lambda_{1}>\lambda_{2}$ esetén a $V_{n}$ mátrixok $v_{n}^{1 \cdot}$-gyel jelölt első sorai m.m. konvergálnak valamilyen véletlen $v^{1 \cdot}$ határértékhez:

$$
\lim v_{n}^{1 \cdot}=v^{1 \cdot} \quad \text { m.m., }
$$

sőt, a [12] dolgozat szerint, $U_{n}$ első oszlopát $u_{n}^{1}$-gyel jelölve,

$$
M_{n}=u_{n}^{\cdot 1} v^{1 \cdot} \sigma_{n}^{1}+O\left(e^{\left(\lambda_{2}+o(1)\right) n}\right) \quad \text { m.m. }
$$

\section{Szekvenciálisan primitív nem-negatív mátrix folyamatok}

Az elkövetkezőkben a nem-negatív mátrixokra vonatkozó primitívség fogalmának a kiterjesztésére lesz szükségünk. Egy szép bevezetés ebbe a témakörbe a [11] dolgozat. Emlékeztetőül, egy $A$ nem-negatív mátrix primitív, ha egy elég magas pozitív egész hatványa, mondjuk $A^{n}$ pozitív. Legyen most $\mathcal{A}$ nem-negatív, $p \times p$-es mátrixok egy tetszőleges családja. Kérdezhetjük, hogy van-e $\mathcal{A}$-beli mátrixoknak olyan szorzata (ismétlést is megengedve), amely szigorúan pozitív. 
3.1. Definíció. Nem-negatív, $p \times p$-es mátrixok egy $\mathcal{A}$ családja primitív, ha létezik $\mathcal{A}$-beli mátrixoknak legalább egy véges szorzata, amely szigorúan pozitív.

A fenti definíció természetes módon kiterjeszthető nem-negatív, $p \times p$-es véletlen mátrixok egy szigorúan stacionárius folyamatára. Előzetesen és emlékeztetőül: egy nem-negatív, $p \times p$-es mátrixot megengedettnek nevezünk, ha nincs azonosan nulla sora vagy oszlopa. Egy mátrix sor-megengedett, ha nincs azonosan nulla sora.

3.2. Definíció. Nem-negatív, megengedett $p \times p$-es véletlen mátrixok egy szigorúan stacionárius $\left(A_{n}\right), n \geq 1$ folyamata szekvenciálisan primitív, ha az $M_{\tau}:=$ $A_{\tau} A_{\tau-1} \cdots A_{1}$ szorzat szigorúan pozitív 1 valószínüséggel valamilyen véges $\tau$ megállási idővel. Tetszőleges $n \geq 1$-re definiáljuk a szekvenciális primitivitási indexet:

$$
\psi_{n}=\min \left\{\psi \geq 1: A_{n+\psi-1} A_{n+\psi-2} \cdots A_{n}>0\right\}
$$

Mivel a definícióban megengedett $A_{n}$ mátrixokra szorítkoztunk, ezek egyben sormegengedettek is, és ezért $M_{n}>0$ szigorú értelemben minden $n \geq \psi_{1}$-re.

3.1. Lemma. Legyen $\left(A_{n}\right), n \geq 1$ nem-negatív, megengedett $p \times p$-es véletlen mátrixok egy azonos, független eloszlású sorozata. Ekkor $\left(A_{n}\right)$ szekvenciálisan primitív akkor és csak akkor, ha az $A_{1}$ véletlen mátrix $\mathbb{R}^{p \times p}$-n vett $\mu$ eloszlásának az $\mathcal{A}=\operatorname{supp} \mu$ tartója primitív.

\section{Nem-negatív mátrixok és vektorok normalizált szorzata}

A relatív konszenzus probléma vizsgálatának egy természetesen kínálkozó eszköze egy nem-negatív mátrixok és vektorok normalizált szorzatára vonatkozó eredmény, nevezetesen az [1] dolgozat 1. Tétele. Ennek önmagában is szép és érdekes közvetlen általánosítását alább ismertetjük. Legyen $\left(A_{n}\right), n \geq 1$ nem-negatív, megengedett $p \times p$-es véletlen mátrixok egy szigorúan stacionárius, ergodikus folyamata. Legyenek $x, w \in \mathbb{R}_{+}^{p}$, azaz legyenek minden komponensükben nem-negatív vektorok, $x, w \geq 0$, és tegyük fel, hogy $x, w \neq 0$. Definiáljuk az alábbi szorzatokat:

$$
\begin{aligned}
x_{n} & :=M_{n} x=A_{n} A_{n-1} \cdots A_{1} x, \\
w_{n} & :=M_{n} w=A_{n} A_{n-1} \cdots A_{1} w .
\end{aligned}
$$

Nyilvánvaló módon $x_{n}, w_{n}$ nem-negatívak, és mivel $A_{n}$ megengedett minden $n$-re és $x, w \neq 0$, következik, hogy $x_{n}, w_{n} \neq 0$ minden $n$-re. Legyen 1 az a $p$-vektor, amelynek minden koordinátája 1. Definiáljuk az alábbi normalizált szorzatokat:

$$
\bar{x}_{n}=x_{n} /\left(\mathbf{1}^{\top} x_{n}\right), \quad \bar{w}_{n}=w_{n} /\left(\mathbf{1}^{\top} w_{n}\right),
$$


valamint a köztük lévő távolságra a totális variáció normát:

$$
\left\|\bar{x}_{n}-\bar{w}_{n}\right\|_{\mathrm{TV}}=\frac{1}{2} \sum_{i=1}^{p}\left|\bar{x}_{n}^{i}-\bar{w}_{n}^{i}\right| .
$$

A következő tétel az [1] dolgozat (hiányos bizonyítású) 1. Tételének közvetlen általánosítása:

4.1. TÉTEL. Legyen $\left(A_{n}\right), n \geq 1$ véletlen mátrixok egy a 2.1. Tétel feltételeinek eleget tevő sorozata. Ezen túlmenően tegyük fel, hogy $A_{n}$ minden n-re nem-negatív, megengedett, és hogy az $\left(A_{n}\right)$ sorozat szekvenciálisan primitív. Ekkor minden $(x, w) \in \mathbb{R}_{+}^{p} \times \mathbb{R}_{+}^{p}, x, w \neq 0$, párra teljesül az alábbi:

$$
\lim _{n} \frac{1}{n} \log \left\|\bar{x}_{n}-\bar{w}_{n}\right\|_{\mathrm{TV}} \leq-\left(\lambda_{1}-\lambda_{2}\right) \quad \text { m.m. }
$$

Az egyenlőtlenség egyenlőséggel teljesül Lebesgue m.m. $(x, w) \in \mathbb{R}_{+}^{p} \times \mathbb{R}_{+}^{p}$ párra. A jobboldal közismert megnevezése spektrális rés (spectral gap).

\section{5. Általánosított relatív konszenzus}

Az általánosított push-sum algoritmusra vonatkozó, konvergenciasebességet is megadó eredmények megfogalmazásában a 4.1. Tétel feltételei alkotnak egy közös keretrendszert, ezt fogjuk kiegészíteni az $\left(A_{n}\right)$ sorozatra vonatkozó egyedi feltételekkel. Nevezetesen, az $A_{n}$ mátrixok pozitív elemeire vonatkozóan fogunk további feltevésekkel élni. Definiáljuk az alábbiakat:

$$
\alpha_{n}:=\min _{i j}\left\{A_{n}^{i j}: A_{n}^{i j}>0\right\}, \quad \beta_{n}:=\max _{i j} A_{n}^{i j} .
$$

Mivel $\beta_{n}$ ekvivalens az $\left\|A_{n}\right\|$ normával, következik, hogy $\mathbb{E} \log ^{+} \beta_{n}<\infty$. Ennek a feltételnek ikerpárja az alábbi $\mathbb{E} \log ^{-} \alpha_{n}>-\infty$ feltétel.

5.1. TÉTEL. Teljesüljenek a 4.1. Tétel feltételei, és legyen az $\left(A_{n}\right)$ sorozat független, azonos eloszlású. Tegyük fel, hogy $\lambda_{1}-\lambda_{2}>0$. Végül tegyük fel, hogy $\mathbb{E} \log ^{-} \alpha_{n}>-\infty$. Legyen $x \in \mathbb{R}^{p}$ kezdeti értékek egy tetszőleges vektora, és legyen $w \in \mathbb{R}_{+}^{p}, w \neq 0$ kezdeti súlyok egy vektora. Ekkor minden $i=1, \ldots, p$-re

$$
\limsup _{n} \frac{1}{n} \log \left|\frac{e_{i}^{\top} M_{n} x}{e_{i}^{\top} M_{n} w}-\frac{v^{1 \cdot} x}{v^{1 \cdot} w}\right| \leq-\left(\lambda_{1}-\lambda_{2}\right) \quad \text { m.m. }
$$

Verbálisan azt mondhatjuk, hogy - a tétel feltételei mellett - a rendszer relatív konszenzusra jut: minden $i$ ágensre az $x_{n}^{i} / w_{n}^{i}$ hányadosok konvergálnak ugyanahhoz a $\pi^{T} x$ értékhez m.m., ahol a $\pi$ véletlen vektorra $\pi=v^{1 \cdot} / v^{1 \cdot} w$. Az $x_{n}^{i} / w_{n}^{i}$ hányados az $i$-dik csúcsban az $n$-dik lépés utáni koncentrációként is értelmezhető. 
A fenti keretrendszer egy kiterjesztését motiválja egy olyan müködésmód, amelyben az egymással kommunikáló párok kiválasztása egy időben homogén véletlen mintázatot követ, amely nem szükségképpen i.i.d., ld. például [2]. Ilymódon megengedjük, hogy $\left(A_{n}\right)$ egy szigorúan stacionárius, ergodikus folyamat legyen. Ebben az esetben két alternatív kiegészítő feltételt fogalmaztunk meg a [4] dolgozatban, itt csak az első, egyszerübb feltételt ismertetjük.

5.2. TÉTEL. Tegyük fel, hogy teljesülnek a 4.1. Tétel feltételei, $\lambda_{1}-\lambda_{2}>0$, és a $\psi_{1}$ szekvenciális primitivitási indexre $\mathbb{E} \psi_{1}<\infty$ (és így $\mathbb{E} \psi_{n}<\infty$ minden $n$-re). Tegyük fel továbbá, hogy az $\left(A_{n}\right)$ sorozat alulról és felülröl korlátos: léteznek olyan $\alpha, \beta>0$ számok, hogy $\alpha_{n} \geq \alpha>0, \beta_{n} \leq \beta$ m.m. Ekkor tetszőleges $x \in \mathbb{R}^{p}$, és $w \in \mathbb{R}_{+}^{p}, w \neq 0$ választás mellett a rendszer relatív konszenzusra jut és fennáll a (21) egyenlötlenség.

Abban a speciális esetben, amikor $A_{n}$ oszlop-sztochasztikus minden $n$-re, ahogy ez fennáll a push-sum algoritmus eredeti formájában, maga az $M_{n}$ szorzatmátrix is oszlop-sztochasztikus lesz minden $n$-re. Ebből könnyen következik, hogy $\lambda_{1}=0$. $\mathrm{Az} M_{n}$ szorzat (14) reprezentációja alapján könnyen megmutatható az is, hogy $v^{1}$. skalár többszöröse a $\mathbf{1}^{\top}$ vektornak. Ilymódon a következő eredményt kapjuk:

5.3. TÉTEL. Tegyük fel, hogy teljesülnek az 5.1., ill. 5.2. Tételek feltételei, és $A_{n}$ oszlop-sztochasztikus minden $n$-re. Ekkor tetszőleges $x \in \mathbb{R}^{p}$ kezdeti vektorra és tetszóleges $w \in \mathbb{R}_{+}^{p}, w \neq 0$ kezdeti súlyvektorra, minden $i=1, \ldots, p$-re

$$
\limsup _{n} \frac{1}{n} \log \left|\frac{e_{i}^{\top} M_{n} x}{e_{i}^{\top} M_{n} w}-\frac{\mathbf{1}^{\top} x}{\mathbf{1}^{\top} w}\right| \leq \lambda_{2}<0 \quad \text { m.m. }
$$

Vegyük észre, a relatív konszenzus által létrejött határérték ebben az esetben determinisztikus, amely a $\pi^{\top} x$ alakban is írható, ahol $\pi=\mathbf{1} / \mathbf{1}^{\top} w$. A $w=\mathbf{1}$ választás esetén az 5.3. Tétel alapján átlag-konszenzus jön létre a klasszikus értelemben: minden $i$ ágensre az $x_{n}^{i} / w_{n}^{i}$ hányadosok konvergálnak az $\bar{x}=\sum_{i=1}^{p} x_{0}^{i} / p$ határértékhez m.m., legalább a tételben adott sebességgel.

Megjegyezzük, hogy az 5.1. és 5.2. Tételekben adott felső korlátok élesek: baloldali hibatagok $i$-ben vett maximumának határértéke pontosan $\lambda_{1}-\lambda_{2}$, ld. [4], 21. Tétel. Az 5.1. és 5.2. Tételek bizonyításainak kiindulópontja az $M_{n}$ szorzat (14) alatt adott reprezentációja.

\section{Specifikáció: a push-sum algoritmus csomagvesztéssel}

A csomagvesztést is megengedő push-sum algoritmus vizsgálatára, ld. [5], az 5.1. Tétel alkalmazható:

6.1. TÉTEL. Legyen $\left(A_{n}\right)$ egy csomagvesztést is megengedö push-sum algoritmushoz társított mátrixok i.i.d. sorozata. Tegyük fel, hogy a $(G, E)$ irányított 
kommunikációs gráf erösen összefüggőo. Ekkor az $\left(A_{n}\right)$ sorozat szekvenciálisan primitív, és $\lambda_{1}>\lambda_{2}$. Következésképpen, tetszőleges $x \in \mathbb{R}^{p}$ kezdeti vektorra és tetszőleges $w \in \mathbb{R}_{+}^{p}, w \neq 0$ kezdeti súlyvektorra, minden $i=1, \ldots, p$-re

$$
\underset{n}{\limsup } \frac{1}{n} \log \left|\frac{e_{i}^{\top} M_{n} x}{e_{i}^{\top} M_{n} w}-\frac{v^{1 \cdot} x}{v^{1 \cdot} w}\right| \leq-\left(\lambda_{1}-\lambda_{2}\right) \quad \text { m.m. }
$$

$\mathrm{Az}\left(A_{n}\right)$ sorozat szekvenciális primitivitása a 3.1. Lemma alapján bizonyítható, amelynek feltétele a hálózat egy csúcsból történő elárasztásával verifikálható, ld. [5], a $\lambda_{1}>\lambda_{2}$ feltétel pedig a 4.1. Tétel alapján bizonyítható, felhasználva az [5] dolgozat exponenciális konvergenciasebességre vonatkozó eredményét (Thm 3).

A csomagvesztést is megengedő push-sum algoritmus esetén a relatív konszenzus által kapott $\pi^{T} x$ érték véletlen, ahol $\pi=v^{1 \cdot} / v^{1 \cdot} w$, de bőséges kísérleti tapasztalat van arra vonatkozóan, hogy a csomagvesztés (ágensektől független) valószínűségének a csökkentésével $\pi^{T} x$ fokozottan koncentrálódik, ld. [5]. Érdekes további kérdés annak vizsgálata, mi a kapcsolat a $\lambda_{1}-\lambda_{2}$ spektrális rés, és a hálózati dinamika paraméterei között.

\section{Köszönetnyilvánítás}

Az első szerző köszönetét fejezi ki Julien M. Hendrickx-nek a konszenzus problémák témakörében folytatott tartós és inspiráló együttmúködésért, továbbá Asuman Ozdaglar-nak a tárgyalt kérdéskörrel kapcsolatos észrevételeiért. Az ő kutatását támogatta az NKFIH PD 121107 sz. pályázata és az MTA Lendület LP 2015-6 sz. pályázata.

\section{Hivatkozások}

[1] R. Atar And O. Zeitouni: Lyapunov exponents for finite state nonlinear filtering, SIAM Journal on Control and Optimization, Vol. 35, pp. 36-55 (1997). DOI: $10.1137 /$ S0363012994272046

[2] F. Bénézit, V. Blondel, P. Thiran, J. Tsitsiklis, and M. Vetterli: Weighted gossip: Distributed averaging using non-doubly stochastic matrices, in Proceedings of 2010 IEEE International Symposium on Information Theory (ISIT), pp. 1753-1757 (2010). DOI: 10.1109/ISIT.2010.5513273

[3] H. Furstenberg and H. Kesten, Products of random matrices, The Annals of Mathematical Statistics, Vol. 31, pp. 457-469 (1960). DOI: 10.1214/aoms/1177705909

[4] B. Gerencsér And L. Gerencsér: Tight bounds on the convergence rate of generalized ratio consensus algorithms. URL: arXiv:1901.11374, 2019. 
[5] B. Gerencsér AND J. M. Hendrickx: Push sum with transmission failures, IEEE Transactions on Automatic Control, Vol. 64, pp. 1019-1033 (2018). DOI: 10.1109/TAC.2018.2836861

[6] R. Jungers: The joint spectral radius: theory and applications, Springer Science \& Business Media, Vol. 385, 2009. DOI: 10.1007/978-3-540-95980-9

[7] D. Kempe, A. Dobra, And J. Gehrke: Gossip-based computation of aggregate information, in Proceedings of 44th Annual IEEE Symposium on Foundations of Computer Science, pp. 482-491 (2003). DOI: 10.1109/SFCS.2003.1238221

[8] D. Kempe and F. McSherry: A decentralized algorithm for spectral analysis, Journal of Computer and System Sciences, Vol. 74, pp. 70-83 (2008). DOI: 10.1016/j.jcss.2007.04.014

[9] V. I. OSELEDEC: A multiplicative ergodic theorem. Liapunov characteristic number for dynamical systems, Transactions of the Moscow Mathematical Society, Vol. 19, pp. 197231 (1968).

[10] G. Picci and T. J. TAYlor: Almost sure exponential convergence to consensus of random gossip algorithms, International Journal of Robust and Nonlinear Control, Vol. 23, pp. 1033-1045 (2013). DOI: 10.1002/rnc.2844

[11] V. Y. Protasov And A. Voynov: Sets of nonnegative matrices without positive products, Linear Algebra and its Applications, Vol. 437, pp. 749-765 (2012). DOI: 10.1016/j.laa.2012.02.029

[12] M. S. Raghunathan: A proof of Oseledec's multiplicative ergodic theorem, Israel Journal of Mathematics, Vol. 32, pp. 356-362 (1979). DOI: 10.1007/BF0276046

[13] A. TAhbaz-Salehi And A. Jadbabaie: Consensus over ergodic stationary graph processes, IEEE Transactions on Automatic Control, Vol. 55, pp. 225-230 (2010). DOI: 10.1109/TAC.2009.2034054

[14] K. I. Tsianos, S. Lawlor and M. G. Rabbat: Push-sum distributed dual averaging for convex optimization, in Proceedings of 2012 IEEE 51st Annual Conference on Decision and Control (CDC), pp. 5453-5458 (2012). DOI: 10.1109/CDC.2012.6426375 


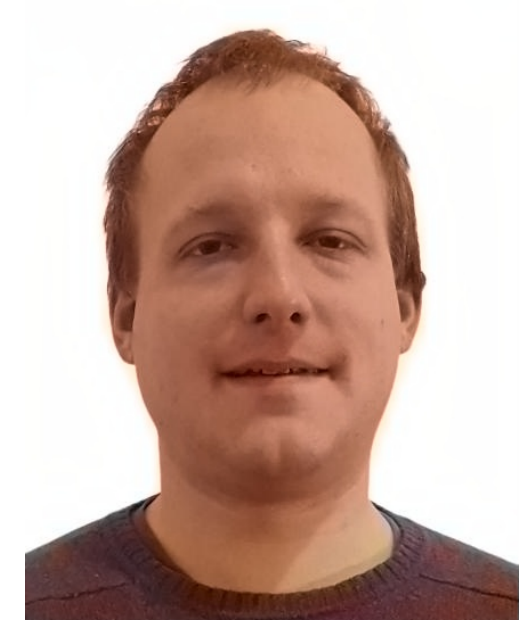

Gerencsér Balázs az ELTE TTK matematikus szakán végezte egyetemi tanulmányait, ahol 2007-ben egyetemi diplomát, majd 2013-ban PhD fokozatot szerzett. A 20092010-es tanévben az MIT vendégkutatója volt (Laboratory for Information and Decision Systems, röviden LIDS) Fulbright hallgatói ösztöndíj támogatásával. Doktori tanulmányai alatt az MTA Rényi Alfréd Matematikai Kutatóintézet alkalmazta tudományos segédmunkatársként, majd fokozatszerzését követően posztdoktori állást kapott a belgiumi Université catholique de Louvain-en, 2013-2015 között. 2015 óta az MTA Rényi Alfréd Matematikai Kutatóintézetben folytatta munkáját posztdoktori ösztöndíjakkal (MTA, NKFIH). 2020-tól az Intézet tudományos fömunkatársa. Kutatómunkája mellett 2016 óta az ELTE Valószínűségelméleti és Statisztika tanszék adjunktusaként oktatói feladatokat is ellát. 2014-ben elnyerte a Bolyai János Matematikai Társulat Farkas Gyula Emlékdíját. Kutatási területei közé tartoznak: Markov láncok keverési tulajdonságai, Markov láncok véletlen környezetben, matematikai genetika, konszenzus problémák és alkalmazásaik, lokális algoritmusok.

\section{GERENCSÉR BALÁZS}

Rényi Alfréd Matematikai Kutatóintézet 1053 Budapest, Reáltanoda utca 13-15.

gerencser.balazs@renyi.hu 


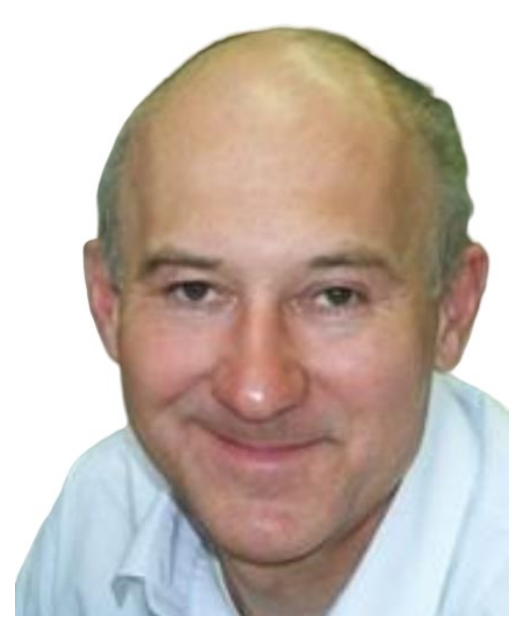

Gerencsér László egyetemi diplomáját az ELTE TTK matematikus szakán szerezte 1969-ben. 1970-től rövidebb-hosszabb megszakításokkal az (MTA) SZTAKI-ban dolgozik az operációkutatás, majd a rendszer- és irányításelmélet témaköreiben. 1988 és 1991 között vendégprofesszor volt a kanadai McGill Egyetemen (Montreal, Quebec), 1997 és 2001 között pedig Széchenyi Professzori Ösztöndíjasként oktatott az ELTE TTK Valószínűségelméleti és Statisztika Tanszékén. Itt matematikus szakon az elsők között oktatott modern pénzügyi matematikát. Több éven át tanított a Pázmány Péter Katolikus Egyetem, Információs Technológiai és Bionikai Karán is.

Témavezetése mellett 8 tanítványa szerzett PhD fokozatot. Az MTA doktora címet 2000-ben kapta meg. Több cikluson át szerkesztőbizottsági tagja volt a SIAM Journal of Control and Optimization, ill. az IEEE Transactions on Automatic Control folyóiratok szerkesztőbizottságainak. Főbb kutatási területei: Sztochasztikus Rendszerek, Változás Detektálás, Pénzügyi Idősorok, Pontfolyamatok, Gépi Tanulás, Elosztott Számítási Modellek.

\title{
GERENCSÉR LÁSZLÓ
}

SZTAKI

1111 Budapest, Kende utca 13-17.

gerencser.laszlo@sztaki.hu

\author{
GENERALIZED RATIO CONSENSUS - \\ TIGHT BOUNDS ON CONVERGENCE RATE
}

\section{Balázs Gerencsér, LÁsZló Gerencsér}

We present a brief summary of recent sharp results of [4] on the convergence of significant generalizations of the push-sum algorithm or weighted gossip algorithm, developed in [7] and [2] for the solution of a ratio consensus problem defined over a network. A key feature of our approach is that we allow a network dynamics to be described by a general strictly stationary, ergodic, sequentially primitive sequence of non-negative matrices. Implications for the exact convergence rate of the push-sum algorithm, including scenarios with packet loss, see [5], will be given.

Keywords: gossip algorithms, ratio consensus, multiplicative ergodic theorems. 